\title{
Gaziantep Yöresi Tarım Topraklarının Besin Elementi Durumları ve Bunların Bazı Toprak Özellikleri ile İlișkileri*
}

\author{
Abdussamet KARADUMAN, Kerim Mesut ÇIMRİ*** \\ MKÜ, Ziraat Fakültesi, Toprak Bilimi ve Bitki Besleme Bölümü, Antakya-Hatay
}

Geliş (Received): 11.02.2016

Kabul (Accepted): 25.03.2016

\begin{abstract}
ÖZET: Çalı̧̧mada, Gaziantep yöresi topraklarının verimlilik durumlarının toprak analizleriyle belirlenmesi amaçlanmıştır. Bu amaçla, yöreyi temsilen 53 noktadan, iki farklı derinlikten $(0-30$ ve 30-60 cm) alınan toplam 106 toprak örneğinde bünye, toplam kireç $\left(\mathrm{CaCO}_{3}\right)$, reaksiyon $(\mathrm{pH})$, toplam tuz, organik madde $(\mathrm{OM})$, katyon değişim kapasitesi (KDK) ve makro-mikro besin elementlerinin analizleri yapılmıştır. Elde edilen bulgulara göre, araştırma alanı topraklarının \% 65.11' inin killi, \% 27.35' inin killi tınlı, \% 7.54' ünün kumlu-killi-tınlı bünyeye sahip olduğu, toprakların büyük bir çoğunluğunun hafif alkalin ve alkalin reaksiyonlu, toprakların organik madde içeriklerinin yetersiz olduğu ve yaklaşık yarısının tuzlu sınıfında yer aldıkları belirlenmiş̧tir. Toprakların \% 55.65' inin azot, \% $35.86^{\prime}$ sının fosfor, \% 39.63' ünün potasyum, \% 29.24' ünün demir, \% 43.40' inın çinko ve \% $2.8^{\prime}$ ' inin bakır bakımlarından yetersiz olduğu belirlenmiştir. Topraklarda $\mathrm{CaCO}_{3}$ ile $\mathrm{pH}$, Tuz, KDK, $\mathrm{K}$ ve $\mathrm{Zn}$; OM ile $\mathrm{P}$, Tuz, KDK ve $\mathrm{pH}$; $\mathrm{pH}$ ile $\mathrm{Zn}$, KDK ve P; KDK ile Kil, Kum, Tuz ve P; Kil ile K, Kum ve Silt; Kum ile Silt ve Cu arsinda önemli iliş̧kiler belirlenmiştir.
\end{abstract}

Anahtar Kelimeler: Gaziantep, toprak verimliliği, toprak özellikleri, besin elementleri

\section{Nutrient Status of Gaziantep Agricultural Soils and Their Relationships with Some Soil Properties}

ABSTRACT: The goal of this study is to determine soil fertility levels of Gaziantep Province, Turkey, through soil analyses. For this objective, a representative soil survey of 53 samplings with two different depths $(0-30$ ve 30-60 $\mathrm{cm}$ ), totaling 106 soil samples, was performed to determine soil texture, lime content, soil $\mathrm{pH}$, total salt, soil organic matter content (SOM), cation exchange capacity (CEC), and macro and micronutrient concentrations. The results showed that clayey, clay loam, and sandy clay loam soils covered $65.11,27.35$, and $7.54 \%$ of the study area, respectively. Most of the soil $\mathrm{pH}$ measurements in the area fell between slightly alkaline and alkaline reactions. Soil organic matter content was deficient in all the region's soils and approximately half of the soils were categorized as saline soils. Deficiency of nitrogen, phosphorous, potassium, iron, zinc, and cupper was determined in 55.65, 35.86, $39.63,29.24,43.4$, and $2.8 \%$ of the soils, respectively. Significant relationships were found for lime with pH, Salt, CEC, K, Zn; SOM with P, Salt, CEC, and pH; pH with Zn, CEC, and P; CEC with Clay, Sand, Salt, and P; Clay with K, Sand, and Silt; Sand with Silt and $\mathrm{Cu}$ in the soils of the study area.

Key Words: Gaziantep, soil fertility, soil properties, nutrient elements

\section{GíRIŞ}

Yeryüzündeki tarımsal üretim alanlarının sınırlı olması ve tarımsal alanların sürekli azalış göstermesi, mevcut tarım alanlarının önemini ortaya koymaktadır. Mevcut tarım alanlarından üretilecek olan ürünlerin artış göstermesini beklemek; toprakların fiziksel, kimyasal ve biyolojik özellikleri ile ilgilidir. Toprak özelliklerinin iyi anlaşılması yetiştirilecek olan ürünün belirlenmesinden girdi kullanımına kadar birçok süreci etkileyen temel faktördür.

Toprakların sahip olduğu besin elementi düzeyleri, nitelikli ve bol ürün için temel kriterdir. Bitki besleme için çevresel faktörlerin yanında toprak parametrelerinin bilinmesi, ortaya konmasi toprak analizlerinin yapılmasını gerekli kılmaktadır. Topraktan eksilen veya toprakta bitki gelişimi için yeterli düzeyde bulunmayan bitki besin maddeleri ancak toprak analizleri sonucu belirlenebilmektedir (Taban ve ark., 2004). Toprakların bitkiye yarayışılı besin maddesi sağlama gücü; toprak pH' s1, kireç, organik madde, bünye, tuz içeriği, katyon değişim kapasitesi gibi çeşitli toprak özellikleri yanında iklim faktörleri başta olmak üzere diğer çevre etmenleri ile yakından ilişkilidir (Özyazıcı ve ark., 2013). Bu nedenle toprak parametrelerinin bilinmesi bitkilerin besin ihtiyacını ve bu ihtiyacın yeterlilik düzeyinin belirlenmesinde büyük önem arz etmektedir. Örnek olarak Cimrin ve Boysan (2006), Van yöresi tarım topraklarının besin elementi durumları ve bunların bazı toprak özellikleri ile ilişkisini belirlemek amacıyla buğday tarımı yapılan alanlardan iki derinlikli olmak üzere 26 noktadan 52 toprak örneğinde besin elementi düzeylerini belirlemiş ve toprakların \% 11.5' inin azotça fakir, \% 36.5' inin orta, \% 46.0' sının iyi, \% 6' sının zengin olduğunu bildirmişlerdir. Ayrıca çalışmada, toprakların \% 30.8' inin fosfor içeriğinin çok az, \% 50' sinin az, \% 19.2' sinin orta düzeyde olduğunu ve Heybeli köyü toprak örnekleri hariç tüm toprak örneklerinin değișebilir potasyum içerikleri bakımından yeter ve çok yüksek

\footnotetext{
*Yüksek Lisans tezinden üretilmiştir.

**Sorumlu yazar: Cimrin, K.M., mcimrin@ hotmail.com
} 
düzeyde oldukları saptanmıştır. Parlak ve ark. (2008), Eceabat ilçesi tarım topraklarından, verimlilik durumlarını belirlemek amacıyla yaptıkları çalışmada 116 adet toprak örneği almışlar ve araştırma sonucunda yöre topraklarının hafif alkali, tuzsuz ve organik madde yönünden düşük düzeyde olduğunu tespit etmişlerdir. Ayrıca toprakların potasyum bakımından yüksek; fosfor, çinko ve mangan içerikleri yönünden yetersiz ve magnezyum, bakır ve demir miktarlarının ise yeterli düzeyde olduğunu belirlemişlerdir. Toprak verimliliği açısından incelendiğinde toprak analiz sonuçlarının bitkilerin besin elementi ihtiyaçlarının karşılanmasında iyi bir rehber olacağı açıktır.

Çalışma Gaziantep ili yaygın toprak gruplarındaki tarım topraklarından farklı iki derinlikten alınan toprakların fiziksel ve kimyasal özellikleri ile bazı makro ve mikro besin element içerikleri belirlenerek, toprakların verimlilik durumlarının ortaya konulması ve besin elementleri ile bazı toprak özellikleri aralarındaki ilişkilerin belirlenmesi amacı ile yapılmıştır.

\section{MATERYAL ve METOT}

Çalışmada, tarım yapılan Gaziantep bölgesi topraklarından yöreyi temsil edecek şekilde, 0 - 30 ve $30-60 \mathrm{~cm}$ olmak üzere iki farklı derinlikten 53 noktadan toplamda 106 toprak örneği, büyük toprak grupları göz önünde tutularak (Anonim, 1992) alınmıştır. Toprak örneklerinin alındıkları yerler ve ilgili büyük toprak grupları Şekil 1 ve Çizelge 1' de gösterilmiş̧tir.

Araştırma sahasından alınan toprak örnekleri, içerisinden bitki artıkları ve taşlar ayıklandıktan sonra, iri kesekler tahta tokmak ile ezilerek, $2 \mathrm{~mm}$ ' lik elekten geçirilerek, plastik kaplarda fiziksel ve kimyasal analizler için saklanmıștır. Toprak örneklerinde, tekstür Bouyoucous hidrometre metodu ile (Bouyoucous 1951), kireç kalsimetrik olarak Allison ve Moodie (1965)'e göre, $\mathrm{pH}$ saturasyon çamurunda Jackson (1958)'a göre, eriyebilir toplam tuz saturasyon çamurunda Richard (1954)'e göre, organik madde modifiye edilmiş Walkley Black metodu ile (Walkley ve Black, 1934), KDK Chapman ve Pratt (1961) tarafindan bildirildiği şekilde amonyum ile saturasyon yöntemine göre belirlenmiştir. Toplam azot Kjeldhal yöntemine göre (Bremner, 1965); alınabilir fosfor sodyum bikarbonat $(\mathrm{pH}=8.5)$ yöntemiyle (Olsen ve ark., 1954); alınabilir potasyum Pratt (1965)'in bildirildiği gibi $1.0 \mathrm{~N}$ nötr (pH: 7.0) amonyum asetat $\left(\mathrm{CH}_{3} \mathrm{COONH}_{4}\right)$ ile ekstrakte edilerek fleymfotometrede, yarayışılı $\mathrm{Fe}, \mathrm{Cu}$, $\mathrm{Zn}$ ve Mn DTPA ile çalkalanarak Lindsay ve Norvell (1978)'e göre yapılmıştır. Elde edilen verilerde korelasyon ve regresyon analizleri SPSS.17 ile değerlendirilerek Düzgüneş ve ark. (1987)'a göre yorumlanmıştır.

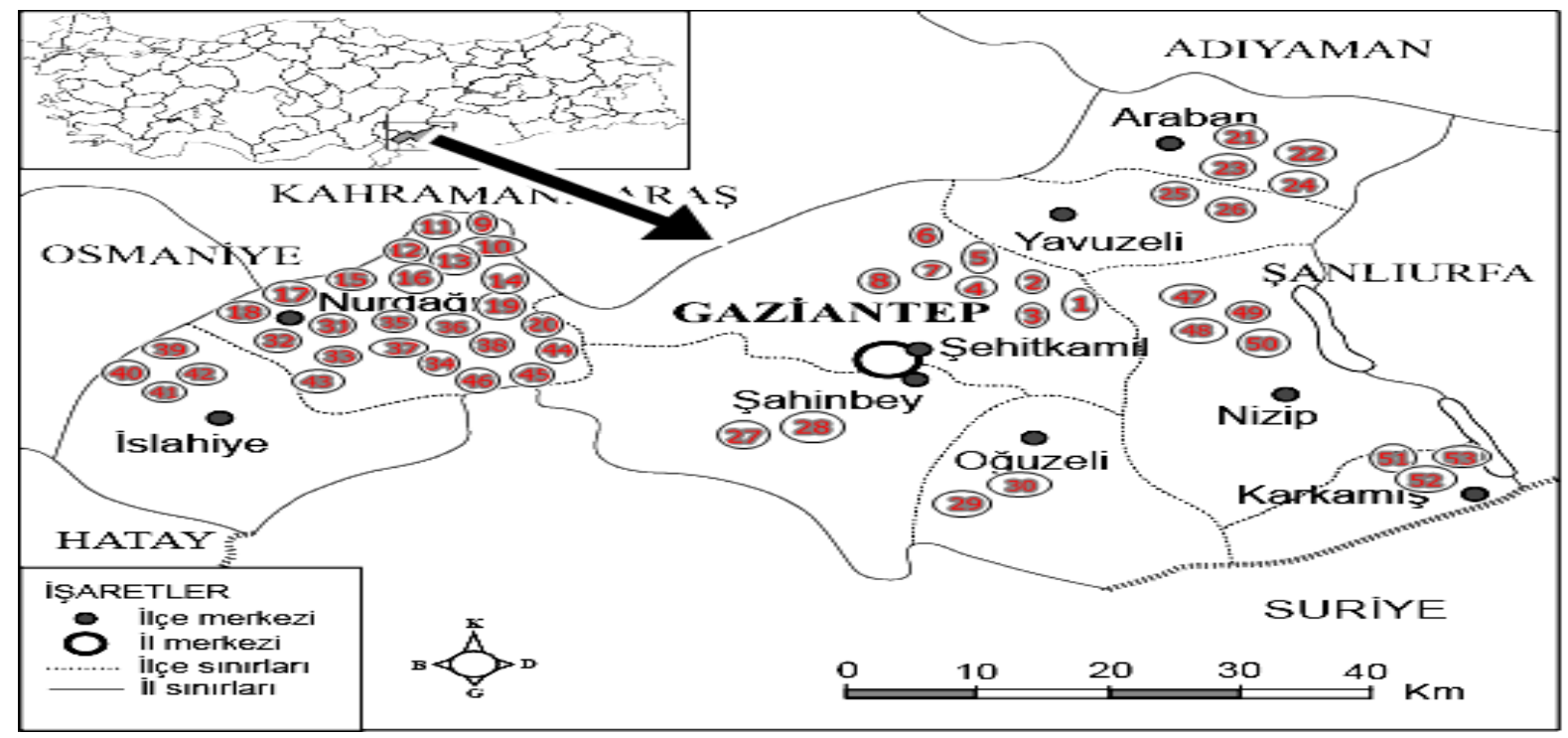

Şekil 1. Alınan toprak örneklerinin Gaziantep ili haritası üzerindeki gösterimi 
Çizelge 1. Toprak örneklerinin alındığı yerler

\begin{tabular}{|c|c|c|c|c|c|}
\hline $\begin{array}{l}\text { Toprak } \\
\text { No } \\
\end{array}$ & Örnek yeri & $\begin{array}{c}\text { Büyük Toprak } \\
\text { Grubu }\end{array}$ & $\begin{array}{c}\text { Toprak } \\
\text { No }\end{array}$ & Örnek yeri & Büyük Toprak Grubu \\
\hline 1 & Gedikli Köyü & Alüvyal & 28 & Kurudere Köyü & Kırm. Kah. Akdeniz. \\
\hline 2 & Gedikli Köyü & Alüvyal & 29 & Gevence Köyü & Kahverengi Toprak \\
\hline 3 & Gedikli Köyü & Alüvyal & 30 & Gevence Köyü & Kahverengi Toprak \\
\hline 4 & Gedikli Köyü & Alüvyal & 31 & Gevence Köÿ̈ & Kahverengi Toprak \\
\hline 5 & Elbistanhüyüğü K. & Alüvyal & 32 & Gevence Köyü & Kahverengi Toprak \\
\hline 6 & Elbistanhüyüğ̆̈̈ K. & Alüvyal & 33 & Karkamış merkezi & Kahverengi Toprak \\
\hline 7 & Elbistanhüyüğü K. & Alüvyal & 34 & Karkamış merkezi & Kahverengi Toprak \\
\hline 8 & Elbistanhüyüğğ $\mathrm{K}$. & Alüvyal & 35 & Karkamış merkezi & Kahverengi Toprak \\
\hline 9 & Çakmak Köyü & Kolüvyal & 36 & Belpınar Köyü & Kireçsiz Kahverengi \\
\hline 10 & Çakmak Köyü & Kolüvyal & 37 & Belpınar Köyü & Kireçsiz Kahverengi \\
\hline 11 & Çakmak Köyü & Kolüvyal & 38 & Belpınar Köyü & Kireçsiz Kahverengi \\
\hline 12 & Çakmak Köyü & Kolüvyal & 39 & Belpınar Köyü & Kireçsiz Kahverengi \\
\hline 13 & İdilli Köyü & Kahverengi Orman & 40 & Fakılı Köyü & Kırmızı Kahverengi \\
\hline 14 & İdilli Köyü & Kahverengi Orman & 41 & Fakılı Köyü & Kırmızı Kahverengi \\
\hline 15 & İdilli Köyü & Kahverengi Orman & 42 & Fakı1lı Köyü & Kırmızı Kahverengi \\
\hline 16 & İdilli Köyü & Kahverengi Orman & 43 & Fakı1ı Köyü & Kırmızı Kahverengi \\
\hline 17 & Toplamalar Köyü & Kireçsiz Kahve. Orman & 44 & Saraymağara Köyü & Kırmızı Kahverengi \\
\hline 18 & Toplamalar Köyü & Kireçsiz Kahve. Orman & 45 & Saraymağara Köyü & Kırmızı Kahverengi \\
\hline 19 & Toplamalar Köyü & Kireçsiz Kahve. Orman & 46 & Bağlarbaş1 Köyü & Kırmızı Kahverengi \\
\hline 20 & Toplamalar Köyü & Kireçsiz Kahve. Orman & 47 & Bağlarbaşı Köyü & Kırmızı Kahverengi \\
\hline 21 & Karacaburç Köyü & Kırmızı Akdeniz & 48 & Acar Köyü & Kırmızı Kahverengi \\
\hline 22 & Karacaburç Köyü & Kırmızı Akdeniz & 49 & Acar Köyü & Kırmızı Kahverengi \\
\hline 23 & Karacaburç Köyü & Kırmızı Akdeniz & 50 & Bağbaşı Köyü & Bazaltik \\
\hline 24 & Karacaburç Köyü & Kırmızı Akdeniz & 51 & Bağbaşı Köyü & Bazaltik \\
\hline 25 & Kurudere Köyü & Kırm. Kahve. Akdeniz & 52 & Bağbaşı Köyü & Bazaltik \\
\hline 26 & Kurudere Köyü & Kırm. Kahve. Akdeniz & 53 & Bağbaşı Köyü & Bazaltik \\
\hline 27 & Kurudere Köyü & Kırm. Kahve. Akdeniz & & & \\
\hline
\end{tabular}

\section{BULGULAR ve TARTIŞMA}

Toprakların Bünye, kireç, pH, tuz, organik madde ve KDK durumları

Gaziantep yöresi topraklarının bazı fiziksel ve kimyasal özellikleri Çizelge 2' de toplu olarak verilmiştir. Çalışma alanı topraklarının kil miktarları \% 24.50 ile \% 57.80 arasında (ortalama $\%$ 41.10), kum miktarları \% 21.16 ile \% 54.06 arasinda (ortalama \%30.93) ve silt miktarları \% 18.00 ile \% 39.84 arasinda (ortalama \%27.96) olduğu belirlenmiştir. Bu toprakların \% 65.09' unun kil, \% 27.36'sının killi tın ve \% 7.55' inin kumlu killi tınlı bünyeye sahip olduğu belirlenmiştir. Tunç ve Özkan (2010) Gaziantep' in tarım topraklarında erozyon sorunu ve bu konuda çiftçi eğitimi isimli çalışmada, toprak örneklerinin ortama kil miktarı \% 39.78, kum miktarı \% 34.81 ve silt miktar1 \% 25.41 olduğu bildirmektedir. Gaziantep topraklarının kireç içeriği durumları değerlendirildiğinde \% 0.10 ile \% 62.33 arasında değiştiği (ortalama kireç içeriği \% 7.87) belirlenmiştir (Çizelge 2). Gaziantep ili toprak gruplarından alınan örnekler, Ülgen ve Yurtsever (1995)' in bildirdiği sınır değerlerine göre sinıflandırıldığında, \% 13.20' si çok fazla kireçli (>\% 25), \% 3.77' si fazla kireçli (\% 15-25), $\% 3.77^{\prime}$ si orta kireçli (\% 5-15), \% 38.67' si az kireçli (\% 1-5) ve \% 40.56' sı çok az kireçli (<\% 1) olarak belirlenmiştir.

Gaziantep topraklarının $\mathrm{pH}$ değerleri 7.01 ile 8.40 arasında değişmekte olup ortalama $\mathrm{pH} 7.74$ olarak belirlenmiştir (Çizelge 2). Gaziantep ili toprak gruplarından alınan örnekler, Kellogg (1952) un bildirdiği sınır değerlerine göre sınıflandırıldığında, toprak pH' larının \% 43.40' 1 alkalin (7.9-8.4), \% 39.62' si hafif alkalin (7.4-7.8) ve $\% 16.98$, inin nötr (6.6-7.3) olduğu belirlenmiştir. Tunç ve Özkan (2010) yörede yaptıkları çalışmada, toprak örneklerinin pH' sının ortalama 7.77 olduğunu bildirmişlerdir. 
Çizelge 2. Gaziantep ili topraklarının fiziksel ve kimyasal özellikleri

\begin{tabular}{|c|c|c|c|c|c|c|c|c|c|c|c|}
\hline Top. Grb. & $\begin{array}{l}\text { Top. } \\
\text { No. }\end{array}$ & $\begin{array}{l}\text { Der. } \\
\mathrm{cm}\end{array}$ & $\begin{array}{c}\text { Kil } \\
\%\end{array}$ & $\underset{\%}{\mathrm{Kum}}$ & $\begin{array}{c}\text { Silt } \\
\%\end{array}$ & Bünye & $\begin{array}{c}\mathrm{CaCO}_{3} \\
\%\end{array}$ & $\begin{array}{l}\mathrm{pH} \\
\text { Sat. }\end{array}$ & $\begin{array}{c}\text { Tuz } \\
\%\end{array}$ & $\begin{array}{c}\text { O.M. } \\
\%\end{array}$ & $\begin{array}{c}\mathrm{KDK} \\
\mathrm{me} / 100 \mathrm{~g}\end{array}$ \\
\hline \multirow{16}{*}{ 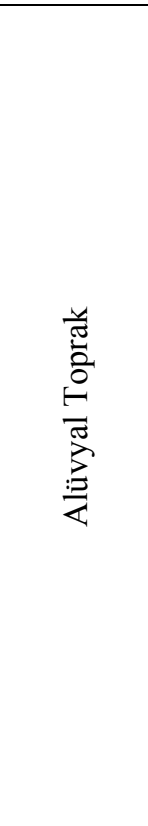 } & \multirow[t]{2}{*}{1} & $0-30$ & 24.62 & 54.06 & 21.32 & SCL & 1.60 & 7.87 & 0.75 & 1.39 & 14.2 \\
\hline & & $30-60$ & 24.50 & 53.18 & 22.32 & SCL & 1.60 & 7.92 & 0.76 & 1.91 & 14.0 \\
\hline & \multirow[t]{2}{*}{2} & $0-30$ & 33.34 & 33.00 & 33.66 & $\mathrm{CL}$ & 0.40 & 7.63 & 1.36 & 1.88 & 28.4 \\
\hline & & $30-60$ & 33.81 & 36.42 & 29.77 & CL & 0.80 & 7.57 & 1.08 & 1.94 & 29.0 \\
\hline & \multirow[t]{2}{*}{3} & $0-30$ & 31.98 & 38.74 & 29.28 & CL & 0.80 & 7.69 & 0.61 & 1.84 & 29.7 \\
\hline & & $30-60$ & 36.44 & 36.12 & 27.44 & $\mathrm{CL}$ & 0.32 & 7.63 & 0.63 & 1.77 & 32.2 \\
\hline & \multirow[t]{2}{*}{4} & $0-30$ & 42.12 & 35.72 & 22.16 & $\mathrm{C}$ & 0.80 & 7.59 & 0.44 & 1.82 & 25.9 \\
\hline & & $30-60$ & 42.86 & 34.24 & 22.90 & $\mathrm{C}$ & 0.40 & 7.63 & 0.65 & 1.98 & 26.1 \\
\hline & \multirow[t]{2}{*}{5} & $0-30$ & 45.12 & 29.64 & 25.24 & $\mathrm{C}$ & 1.50 & 7.95 & 0.64 & 1.08 & 29.1 \\
\hline & & $30-60$ & 48.40 & 28.16 & 23.44 & $\mathrm{C}$ & 1.00 & 7.72 & 0.74 & 1.21 & 30.2 \\
\hline & \multirow[t]{2}{*}{6} & $0-30$ & 43.76 & 30.08 & 26.16 & $\mathrm{C}$ & 0.60 & 7.63 & 0.55 & 0.89 & 32.4 \\
\hline & & $30-60$ & 43.32 & 30.02 & 26.66 & $\mathrm{C}$ & 0.80 & 7.68 & 0.60 & 1.71 & 32.0 \\
\hline & \multirow[t]{2}{*}{7} & $0-30$ & 45.14 & 33.42 & 21.44 & $\mathrm{C}$ & 1.60 & 8.27 & 0.40 & 0.73 & 25.6 \\
\hline & & $30-60$ & 48.60 & 32.40 & 19.00 & $\mathrm{C}$ & 1.20 & 7.70 & 0.70 & 0.80 & 26.7 \\
\hline & \multirow[t]{2}{*}{8} & $0-30$ & 44.20 & 29.48 & 26.32 & $\mathrm{C}$ & 0.80 & 7.83 & 0.50 & 1.27 & 32.8 \\
\hline & & $30-60$ & 43.84 & 28.20 & 27.96 & $\mathrm{C}$ & 1.20 & 7.65 & 0.58 & 0.84 & 32.1 \\
\hline \multirow{8}{*}{ 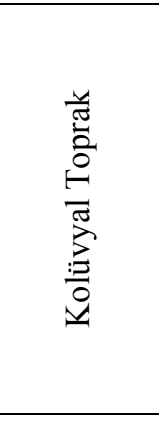 } & \multirow[t]{2}{*}{9} & $0-30$ & 48.26 & 30.52 & 21.22 & $\mathrm{C}$ & 0.40 & 7.71 & 0.81 & 1.24 & 24.8 \\
\hline & & $30-60$ & 48.14 & 28.76 & 23.10 & $\mathrm{C}$ & 0.60 & 7.67 & 1.28 & 1.33 & 24.2 \\
\hline & \multirow[t]{2}{*}{10} & $0-30$ & 45.32 & 31.34 & 23.34 & $\mathrm{C}$ & 0.80 & 7.83 & 1.36 & 1.34 & 25.1 \\
\hline & & $30-60$ & 44.36 & 30.22 & 25.42 & $\mathrm{C}$ & 0.80 & 7.80 & 1.33 & 1.52 & 24.8 \\
\hline & \multirow[t]{2}{*}{11} & $0-30$ & 44.64 & 30.58 & 24.78 & $\mathrm{C}$ & 0.24 & 7.47 & 0.84 & 0.93 & 27.4 \\
\hline & & $30-60$ & 42.48 & 29.64 & 27.88 & $\mathrm{C}$ & 0.24 & 7.45 & 0.81 & 0.95 & 27.1 \\
\hline & \multirow[t]{2}{*}{12} & $0-30$ & 44.86 & 30.47 & 24.67 & $\mathrm{C}$ & 0.48 & 7.58 & 1.04 & 0.87 & 25.6 \\
\hline & & $30-60$ & 44.42 & 29.98 & 25.60 & $\mathrm{C}$ & 0.40 & 7.59 & 0.68 & 1.40 & 25.2 \\
\hline \multirow{8}{*}{ 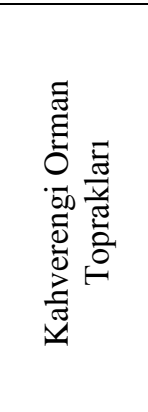 } & 13 & $0-30$ & 52.40 & 26.96 & 20.64 & $\mathrm{C}$ & 1.20 & 8.08 & 0.46 & 1.46 & 42.1 \\
\hline & \multirow{3}{*}{14} & $30-60$ & 51.20 & 25.44 & 23.36 & $\mathrm{C}$ & 1.60 & 7.55 & 0.39 & 1.65 & 42.0 \\
\hline & & $0-30$ & 35.12 & 36.62 & 28.26 & CL & 4.20 & 7.14 & 0.44 & 1.64 & 38.3 \\
\hline & & $30-60$ & 35.82 & 34.60 & 29.58 & CL & 0.40 & 7.87 & 0.57 & 0.53 & 38.4 \\
\hline & \multirow[t]{2}{*}{15} & $0-30$ & 51.24 & 26.42 & 22.34 & $\mathrm{C}$ & 1.60 & 8.13 & 0.38 & 0.91 & 41.2 \\
\hline & & $30-60$ & 52.62 & 24.12 & 23.26 & $\mathrm{C}$ & 1.60 & 8.05 & 0.35 & 1.41 & 42.5 \\
\hline & \multirow[t]{2}{*}{16} & $0-30$ & 52.48 & 25.20 & 22.32 & C & 3.20 & 8.02 & 0.44 & 0.90 & 42.7 \\
\hline & & $30-60$ & 57.80 & 21.74 & 20.46 & $\mathrm{C}$ & 3.60 & 8.06 & 0.47 & 0.90 & 44.4 \\
\hline
\end{tabular}


Çizelge 2. (Devam)

\begin{tabular}{|c|c|c|c|c|c|c|c|c|c|c|c|}
\hline Top. Grb. & $\begin{array}{l}\text { Top. } \\
\text { No. }\end{array}$ & $\begin{array}{l}\text { Der. } \\
\mathrm{cm}\end{array}$ & $\begin{array}{c}\text { Kil } \\
\%\end{array}$ & $\underset{\%}{\mathrm{Kum}}$ & $\begin{array}{c}\text { Silt } \\
\%\end{array}$ & Bünye & $\begin{array}{c}\mathrm{CaCO}_{3} \\
\%\end{array}$ & $\begin{array}{l}\text { pH } \\
\text { Sat. }\end{array}$ & $\begin{array}{c}\text { Tuz } \\
\%\end{array}$ & $\begin{array}{c}\text { O.M. } \\
\%\end{array}$ & $\begin{array}{c}\mathrm{KDK} \\
\mathrm{me} / 100 \mathrm{~g}\end{array}$ \\
\hline \multirow{8}{*}{ 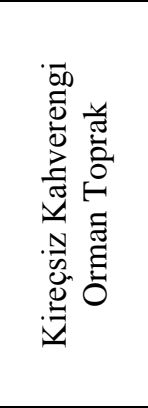 } & 17 & $0-30$ & 41.40 & 30.24 & 28.36 & $\mathrm{C}$ & 1.00 & 7.58 & 0.46 & 0.58 & 31.3 \\
\hline & & $30-60$ & 43.12 & 29.78 & 27.10 & $\mathrm{C}$ & 1.00 & 7.36 & 0.49 & 1.00 & 32.2 \\
\hline & 18 & $0-30$ & 42.60 & 32.72 & 24.68 & $\mathrm{C}$ & 1.20 & 7.18 & 0.77 & 1.67 & 33.5 \\
\hline & & $30-60$ & 44.06 & 30.16 & 25.78 & $\mathrm{C}$ & 1.00 & 7.14 & 0.69 & 1.67 & 33.9 \\
\hline & 19 & $0-30$ & 42.22 & 30.40 & 27.38 & $\mathrm{C}$ & 0.80 & 7.16 & 0.68 & 1.78 & 34.0 \\
\hline & & $30-60$ & 42.84 & 30.02 & 27.14 & $\mathrm{C}$ & 0.10 & 7.23 & 0.69 & 1.53 & 34.2 \\
\hline & 20 & $0-30$ & 43.98 & 29.64 & 26.38 & $\mathrm{C}$ & 2.40 & 7.21 & 0.67 & 1.34 & 32.8 \\
\hline & & $30-60$ & 44.00 & 29.20 & 26.80 & $\mathrm{C}$ & 1.20 & 7.22 & 0.64 & 1.48 & 33.7 \\
\hline \multirow{8}{*}{ 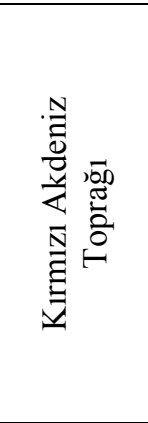 } & 21 & $0-30$ & 37.48 & 32.64 & 29.88 & $\mathrm{CL}$ & 9.20 & 7.96 & 0.61 & 0.78 & 31.8 \\
\hline & & $30-60$ & 37.36 & 30.72 & 31.92 & $\mathrm{CL}$ & 8.00 & 7.96 & 0.60 & 0.78 & 31.2 \\
\hline & 22 & $0-30$ & 35.98 & 34.22 & 29.80 & CL & 8.80 & 8.00 & 0.48 & 0.43 & 37.0 \\
\hline & & $30-60$ & 28.19 & 31.97 & 39.84 & $\mathrm{CL}$ & 4.64 & 8.03 & 0.42 & 0.62 & 36.6 \\
\hline & 23 & $0-30$ & 32.42 & 36.74 & 30.84 & CL & 1.92 & 7.94 & 0.36 & 0.38 & 37.5 \\
\hline & & $30-60$ & 35.39 & 34.93 & 29.68 & $\mathrm{CL}$ & 2.08 & 7.95 & 0.38 & 0.69 & 38.2 \\
\hline & 24 & $0-30$ & 38.67 & 31.38 & 29.95 & $\mathrm{CL}$ & 3.04 & 7.76 & 0.35 & 0.40 & 35.4 \\
\hline & & $30-60$ & 34.92 & 25.34 & 39.74 & $\mathrm{CL}$ & 2.80 & 7.76 & 0.33 & 0.69 & 35.0 \\
\hline \multirow{8}{*}{ 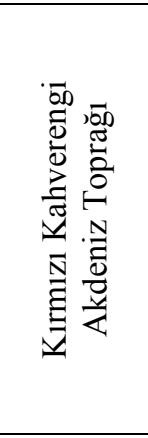 } & 25 & $0-30$ & 36.02 & 28.18 & 35.80 & $\mathrm{CL}$ & 0.40 & 7.41 & 0.57 & 1.22 & 36.2 \\
\hline & & $30-60$ & 36.14 & 27.86 & 36.00 & CL & 0.80 & 7.45 & 0.60 & 1.19 & 36.5 \\
\hline & 26 & $0-30$ & 42.64 & 25.00 & 32.36 & $\mathrm{C}$ & 0.40 & 7.48 & 0.30 & 0.61 & 36.1 \\
\hline & & $30-60$ & 42.98 & 24.18 & 32.84 & $\mathrm{C}$ & 0.80 & 7.52 & 0.35 & 0.29 & 36.6 \\
\hline & 27 & $0-30$ & 53.40 & 25.92 & 20.68 & $\mathrm{C}$ & 0.64 & 7.60 & 0.37 & 0.26 & 42.4 \\
\hline & & $30-60$ & 43.63 & 25.20 & 31.17 & $\mathrm{C}$ & 0.96 & 7.58 & 0.33 & 0.26 & 39.7 \\
\hline & 28 & $0-30$ & 46.82 & 29.36 & 23.82 & $\mathrm{C}$ & 0.48 & 7.60 & 0.65 & 0.04 & 29.4 \\
\hline & & $30-60$ & 49.00 & 29.10 & 21.90 & $\mathrm{C}$ & 0.72 & 7.65 & 0.68 & 0.14 & 31.0 \\
\hline \multirow{14}{*}{ 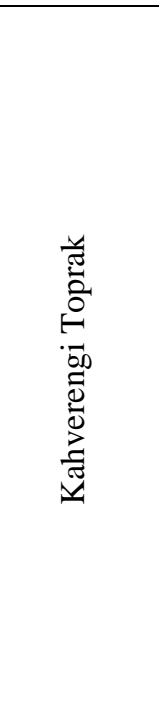 } & 29 & $0-30$ & 40.26 & 26.04 & 33.70 & $\mathrm{C}$ & 46.75 & 8.11 & 0.71 & 1.39 & 33.7 \\
\hline & & $30-60$ & 40.12 & 25.80 & 34.08 & $\mathrm{C}$ & 45.97 & 7.93 & 0.35 & 0.95 & 32.4 \\
\hline & 30 & $0-30$ & 42.18 & 27.14 & 30.68 & $\mathrm{C}$ & 45.19 & 8.13 & 0.41 & 1.19 & 32.1 \\
\hline & & $30-60$ & 52.16 & 26.20 & 21.67 & $\mathrm{C}$ & 46.75 & 7.96 & 0.39 & 1.57 & 35.2 \\
\hline & 31 & $0-30$ & 48.06 & 28.62 & 23.32 & $\mathrm{C}$ & 49.09 & 8.10 & 0.67 & 1.63 & 34.3 \\
\hline & & $30-60$ & 50.21 & 26.48 & 23.31 & $\mathrm{C}$ & 62.33 & 7.95 & 0.33 & 1.45 & 35.8 \\
\hline & 32 & $0-30$ & 40.34 & 27.43 & 32.23 & $\mathrm{C}$ & 44.80 & 8.13 & 0.47 & 1.30 & 33.2 \\
\hline & & $30-60$ & 42.12 & 26.20 & 31.62 & $\mathrm{C}$ & 46.36 & 8.11 & 0.39 & 1.19 & 34.1 \\
\hline & 33 & $0-30$ & 36.12 & 27.23 & 36.65 & $\mathrm{CL}$ & 0.32 & 8.04 & 0.34 & 1.55 & 32.4 \\
\hline & & $30-60$ & 34.12 & 26.47 & 39.41 & CL & 0.55 & 8.33 & 0.50 & 1.36 & 32.2 \\
\hline & 34 & $0-30$ & 36.24 & 30.10 & 33.66 & CL & 5.65 & 8.36 & 0.33 & 1.04 & 37.5 \\
\hline & & $30-60$ & 34.37 & 30.14 & 35.49 & $\mathrm{CL}$ & 3.97 & 8.40 & 0.33 & 1.54 & 37.3 \\
\hline & 35 & $0-30$ & 34.42 & 30.25 & 35.33 & $\mathrm{CL}$ & 34.28 & 7.96 & 0.36 & 1.39 & 37.0 \\
\hline & & $30-60$ & 34.20 & 30.08 & 35.72 & CL & 32.72 & 7.99 & 0.40 & 1.78 & 36.6 \\
\hline
\end{tabular}


Çizelge 2. (Devam)

\begin{tabular}{|c|c|c|c|c|c|c|c|c|c|c|c|}
\hline $\begin{array}{l}\text { Top. } \\
\text { Grb. }\end{array}$ & $\begin{array}{l}\text { Top. } \\
\text { No. }\end{array}$ & $\begin{array}{c}\text { Der. } \\
\mathrm{cm}\end{array}$ & $\begin{array}{c}\text { Kil } \\
\%\end{array}$ & $\underset{\%}{\text { Kum }}$ & $\begin{array}{l}\text { Silt } \\
\%\end{array}$ & Bünye & $\begin{array}{c}\mathrm{CaCO}_{3} \\
\%\end{array}$ & $\begin{array}{l}\mathrm{pH} \\
\text { Sat. }\end{array}$ & $\begin{array}{c}\text { Tuz } \\
\%\end{array}$ & $\begin{array}{c}\text { O.M. } \\
\%\end{array}$ & $\begin{array}{c}\mathrm{KDK} \\
\mathrm{me} / 100 \\
\mathrm{~g}\end{array}$ \\
\hline \multirow{8}{*}{ 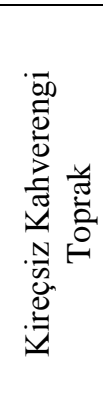 } & 36 & $0-30$ & 44.60 & 25.42 & 29.98 & $\mathrm{C}$ & 1.20 & 7.18 & 1.01 & 0.26 & 33.8 \\
\hline & & $30-60$ & 45.48 & 25.20 & 29.32 & $\mathrm{C}$ & 1.40 & 7.20 & 1.04 & 0.12 & 34.0 \\
\hline & 37 & $0-30$ & 43.18 & 24.44 & 32.38 & $\mathrm{C}$ & 0.40 & 7.10 & 1.09 & 1.49 & 32.5 \\
\hline & & $30-60$ & 49.56 & 22.74 & 27.70 & $\mathrm{C}$ & 1.80 & 7.15 & 1.12 & 1.48 & 32.9 \\
\hline & 38 & $0-30$ & 41.16 & 23.90 & 34.94 & $\mathrm{C}$ & 1.40 & 7.10 & 0.83 & 1.12 & 32.1 \\
\hline & & $30-60$ & 42.60 & 22.84 & 34.56 & $\mathrm{C}$ & 1.80 & 7.12 & 0.86 & 1.08 & 32.3 \\
\hline & 39 & $0-30$ & 41.62 & 24.32 & 34.06 & $\mathrm{C}$ & 1.80 & 7.01 & 0.78 & 0.46 & 21.8 \\
\hline & & $30-60$ & 41.24 & 23.40 & 35.36 & $\mathrm{C}$ & 1.00 & 7.05 & 0.81 & 0.41 & 21.2 \\
\hline \multirow{20}{*}{ 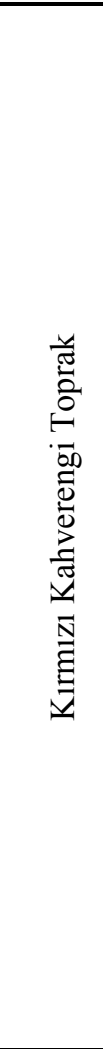 } & 40 & $0-30$ & 42.24 & 29.56 & 28.20 & $\mathrm{C}$ & 2.40 & 8.00 & 0.92 & 1.58 & 23.7 \\
\hline & & $30-60$ & 42.10 & 29.41 & 28.49 & $\mathrm{C}$ & 1.60 & 7.05 & 0.80 & 1.43 & 23.3 \\
\hline & 41 & $0-30$ & 43.70 & 29.78 & 26.52 & $\mathrm{C}$ & 2.80 & 7.83 & 1.19 & 1.36 & 24.8 \\
\hline & & $30-60$ & 41.54 & 28.40 & 30.06 & $\mathrm{C}$ & 2.88 & 7.89 & 1.21 & 1.29 & 24.2 \\
\hline & 42 & $0-30$ & 40.16 & 27.32 & 32.52 & $\mathrm{C}$ & 1.68 & 7.78 & 0.98 & 1.58 & 34.8 \\
\hline & & $30-60$ & 41.28 & 26.87 & 31.85 & $\mathrm{C}$ & 2.00 & 7.80 & 1.01 & 1.51 & 35.2 \\
\hline & 43 & $0-30$ & 40.17 & 27.20 & 32.63 & $\mathrm{C}$ & 1.92 & 7.85 & 1.06 & 1.55 & 35.1 \\
\hline & & $30-60$ & 40.02 & 27.14 & 32.84 & $\mathrm{C}$ & 1.60 & 7.81 & 1.18 & 1.03 & 34.3 \\
\hline & 44 & $0-30$ & 33.60 & 48.40 & 18.00 & SCL & 0.47 & 8.20 & 0.52 & 0.98 & 40.2 \\
\hline & & $30-60$ & 33.12 & 46.88 & 20.00 & SCL & 0.39 & 8.22 & 0.68 & 0.98 & 41.5 \\
\hline & 45 & $0-30$ & 34.44 & 30.65 & 34.91 & CL & 0.39 & 8.19 & 0.44 & 1.01 & 29.9 \\
\hline & & $30-60$ & 28.27 & 43.02 & 28.71 & $\mathrm{CL}$ & 0.47 & 7.87 & 1.09 & 1.30 & 28.7 \\
\hline & 46 & $0-30$ & 31.80 & 39.66 & 28.54 & CL & 42.85 & 7.93 & 0.33 & 0.89 & 39.1 \\
\hline & & $30-60$ & 38.67 & 34.38 & 26.95 & $\mathrm{CL}$ & 45.19 & 7.33 & 0.32 & 0.33 & 42.0 \\
\hline & 47 & $0-30$ & 35.81 & 35.67 & 28.52 & $\mathrm{CL}$ & 35.06 & 8.25 & 0.74 & 0.86 & 36.7 \\
\hline & & $30-60$ & 36.74 & 34.54 & 28.72 & $\mathrm{CL}$ & 35.84 & 8.18 & 0.81 & 0.71 & 36.8 \\
\hline & 48 & $0-30$ & 31.60 & 47.12 & 21.28 & SCL & 20.26 & 8.13 & 1.19 & 1.33 & 31.5 \\
\hline & & $30-60$ & 31.42 & 46.96 & 21.62 & SCL & 22.59 & 8.13 & 0.58 & 1.25 & 30.2 \\
\hline & 49 & $0-30$ & 30.14 & 48.28 & 21.58 & SCL & 20.26 & 7.75 & 0.55 & 1.19 & 35.3 \\
\hline & & $30-60$ & 30.22 & 48.06 & 21.72 & SCL & 20.39 & 8.08 & 0.78 & 0.92 & 35.9 \\
\hline \multirow{8}{*}{ 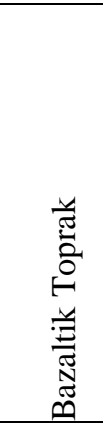 } & 50 & $0-30$ & 44.12 & 36.02 & 19.86 & $\mathrm{C}$ & 0.88 & 7.95 & 1.28 & 1.36 & 22.9 \\
\hline & & $30-60$ & 44.24 & 35.12 & 20.64 & $\mathrm{C}$ & 0.72 & 7.91 & 1.18 & 1.27 & 23.0 \\
\hline & 51 & $0-30$ & 44.72 & 21.16 & 34.12 & $\mathrm{C}$ & 0.96 & 7.92 & 1.64 & 0.97 & 28.8 \\
\hline & & $30-60$ & 48.42 & 23.46 & 28.12 & $\mathrm{C}$ & 0.88 & 7.95 & 1.66 & 0.85 & 29.6 \\
\hline & 52 & $0-30$ & 43.72 & 27.75 & 28.53 & $\mathrm{CL}$ & 0.88 & 7.93 & 1.39 & 1.04 & 24.4 \\
\hline & & $30-60$ & 43.56 & 26.84 & 29.60 & $\mathrm{C}$ & 0.64 & 7.96 & 1.10 & 0.73 & 24.2 \\
\hline & 53 & $0-30$ & 44.82 & 29.42 & 25.76 & $\mathrm{C}$ & 0.80 & 7.59 & 1.58 & 0.55 & 22.5 \\
\hline & & $30-60$ & 43.64 & 28.73 & 27.63 & $\mathrm{C}$ & 0.90 & 7.55 & 1.26 & 0.72 & 22.1 \\
\hline \multicolumn{2}{|c|}{ En Büyük } & & 57.80 & 54.06 & 39.84 & & 62.33 & 8.40 & 1.66 & 1.98 & 44.4 \\
\hline \multicolumn{2}{|c|}{ En Küçük } & & 24.50 & 21.16 & 18.00 & & 0.10 & 7.01 & 0.30 & 0.04 & 14.0 \\
\hline \multicolumn{2}{|c|}{ Ortalama } & & 41.10 & 30.93 & 27.96 & & 7.87 & 7.74 & 0.71 & 1.11 & 32.0 \\
\hline
\end{tabular}


Gaziantep topraklarının tuz içerikleri \% 0.30 ile \% 1.66 arasında değişmekte olup ortalama tuz içeriği \% 0.71 olarak belirlenmiştir (Çizelge 2). Gaziantep ili toprakları, Tüzüner (1990)' de bildirilen sınır değerlere göre sınıflandırıldığında, tuz içeriklerinin \% 47.16' sının çok fazla tuzlu ( $>\%$ $0.65), \% 42.45$ ' inin orta derecede tuzlu $(\% 0.35$ $0.65)$ ve $\% 10.39$ ' unun hafif tuzlu (\% $0.15-0.35)$ olduğu belirlenmiştir.

Gaziantep topraklarının organik madde içerikleri \% 0.04 ile \% 1.98 arasında değişmekte olup ortalama \% 1.11 olarak belirlenmiştir (Çizelge 2). Gaziantep ili toprakları, Anonim (1988)' de bildirilen sınır değerlerine göre sınıflandırıldığında, organik madde içerikleri toprakların \% 59.43' de az (\% 1-2) ve \% 40.57' sinde çok az (<\% 1) olduğu belirlenmiştir. Benzer olarak Köksal ve ark. (2003), antepfıstığında periyodisite üzerine etkili faktörlerin ve etki düzeylerinin belirlenmesi amaciyla yaptıkları çalışmada, Gaziantep yöresinden alınan toprak örneklerinin ortalama organik madde içeriğinin \% 1.22 olduğunu bildirmişlerdir.

Gaziantep topraklarının tüm gruplarının katyon değişim kapasiteleri, 14 me / 100 g ile 44 me / 100 g arasında değiştiği bulunmuştur (Çizelge 2).

Toprak örneklerinin bazı bitki besin elementi içerikleri

Gaziantep yöresi topraklarının $\mathrm{N}, \mathrm{P}, \mathrm{K}, \mathrm{Fe}, \mathrm{Cu}$, $\mathrm{Zn}$ ve Mn içerikleri Çizelge 3' de verilmiştir. Gaziantep topraklarının toplam azot içeriği \% 0.003 ile \% 0.323 arasında değişerek ortalama toplam azot içeriği \% 0.090 olarak belirlenmiştir (Çizelge 3). Gaziantep toprakları, Sillanpää (1990)' da belirlenen sınır değerlerine göre sinıflandırıldığında toprakların toplam azot içerikleri bakımından \% 0.96 ' sinın çok fazla (> \% 0.320$), \% 11.32$ ' $\operatorname{sinin}$ fazla (\% $0.170-0.320), \% 32.07$ ' sinin yeterli $(\%$ $0.090-0.170), \% 33.01$ ' inin az (\% 0.045-0.090) ve $\%$ 22.64' ünün çok az (< \% 0.045$)$ olduğu belirlenmiştir.

Gaziantep topraklarının yarayışlı fosfor içeriği değerlendirildiğinde 1.65 ppm ile 50.27 ppm arasında değişmekte olup ortalama yarayışlı fosfor içeriği 13.88 ppm olarak belirlenmiştir (Çizelge 3). Gaziantep ili toprak gruplarından alınan örneklerin yarayışlı fosfor içerikleri, Sillanpää (1990)' da belirlenen sınır değerlerine göre sinıflandırıldığında \% 13.20' sinin fazla (25-80 ppm), \% 50.94' ünün yeterli (8-25 ppm), $\%$ 34.90' ının az (2.5-8 ppm) ve \% 0.96' sının çok az $(<2.5 \mathrm{ppm})$ olduğu belirlenmiştir.

Gaziantep topraklarının yarayışlı potasyum içeriği değerlendirildiğinde 29.20 ppm ile 647.40 ppm arasında değişmekte olup ortalama 153.12 ppm olarak belirlenmiştir (Çizelge 3).

Gaziantep topraklarının yarayışlı potasyum içerikleri Sillanpää (1990)'da belirlenen sınır değerlerine göre sınıflandırıldığında, \% 8.49' unun fazla (290-1000 ppm), \% 51.88' inin yeterli (110290 ppm), \% 33.96' sinın az (50-110 ppm) ve \% 5.67 ' sinin çok az $(<50 \mathrm{ppm})$ olarak belirlenmiştir. Buna göre, yörede toprakların \% 40' inda potasyum gübrelemesine ihtiyaç vardır.

Gaziantep topraklarının yarayışlı demir içeriği 1.03 ppm ile 13.95 ppm arasında değişmekte olup ortalama yarayışlı demir içeriği 4.99 ppm olarak belirlenmiştir (Çizelge 3). Gaziantep topraklarının yarayışı demir içerikleri Lindsay ve Norvell (1978)' de belirlenen sınır değerlerine göre sınıflandırıldığında \% 45.28' inin fazla ( $>4.5 \mathrm{ppm})$, \% 25.48' inin orta (2.5-4.5 ppm) ve \% 29.24' ünün az $(<2.5 \mathrm{ppm})$ derecede olduğu belirlenmiştir. Eryüce ve ark. (1993), Gaziantep yöresinden alınan toprak örneklerinin \% 64' ünün demir içeriklerinin fazla ve orta düzeyde olduğunu bildirmişlerdir.

Gaziantep topraklarının yarayışlı bakır içeriği, 0.14 ppm ile 3.15 ppm arasında değişmekte olup ortalama yarayışlı bakır içeriği 1.04 ppm olarak belirlenmiştir (Çizelge 3). Gaziantep ili topraklarının yarayışlı bakır içerikleri Follet ve Lindsay (1978)' de belirlenen sınır değerlerine göre sinıflandırıldığında \% 97.16' sinın yeterli ( $>0.2$ ppm), \% 2.84' ünün yetersiz (<0.2 ppm) olduğu belirlenmiştir. Eryüce ve ark. (1993), Gaziantep ve civarındaki illerin mikro element düzeylerini belirlemek amacıyla yaptıkları çalışmada, yöreden alınan toprakların bakır içeriklerinin $0.50 \mathrm{ppm}$ ile $6.10 \mathrm{ppm}$ arasında değiştiğini ve çalışılan iller arasında en yüksek $\mathrm{Cu}$ içeriğine sahip toprakların Gaziantep yöresinde olduğunu bildirmişlerdir.

Gaziantep topraklarının yarayışlı çinko içeriği değerlendirildiğinde 0.20 ppm ile 3.94 ppm arasında değişmekte olup ortalama yarayışlı çinko içeriği 1.16 ppm olarak belirlenmiştir (Çizelge 3). Gaziantep topraklarının yarayışlı çinko içerikleri, Sillanpää (1990)' da belirlenen sınır değerlerine göre sınıflandırıldığında \% 9.44' ünün fazla (2.4$8.0 \mathrm{ppm}), \%$ 47.16' sinın yeterli (0.7-2.4 ppm), \% 43.40' ının az (0.2-0.7 ppm) olduğu belirlenmiştir. $\mathrm{Bu}$ durum yöre topraklarının en az \% 43' ünde $\mathrm{Zn}$ gübrelemesi gerektiğini göstermektedir.

Gaziantep topraklarının yarayışlı mangan içeriğ $i$ değerlendirildiğinde $4.98 \mathrm{ppm}$ ile $28.65 \mathrm{ppm}$ arasında değişmekte olup ortalama yarayışlı mangan içeriği 13.26 ppm olarak belirlenmiştir (Çizelge 3). Gaziantep ili topraklarının yarayışlı mangan içerikleri Follet ve Lindsay (1970)' de belirlenen sınır değerlerine göre sınıflandırıldığında tamamının yeterli (> $1.00 \quad \mathrm{ppm})$ olduğu belirlenmiştir. Eryüce ve ark. (1993), yörede yaptıkları benzer bir çalışmada, yöreyi temsil eden topraklara ait yarayışlı $\mathrm{Mn}$ değerlerinin $5.34 \mathrm{ppm}$ ile $31 \mathrm{ppm}$ aralıklarında olduğu bildirilmektedir. 
Çizelge 3. Gaziantep ili topraklarının N, P, K, Fe, Cu, Zn ve Mn içerikleri

\begin{tabular}{|c|c|c|c|c|c|c|c|c|c|}
\hline $\begin{array}{c}\text { Toprak } \\
\text { Grb. }\end{array}$ & $\begin{array}{c}\text { Örnek } \\
\text { No. }\end{array}$ & $\begin{array}{c}\text { Derinlik } \\
\mathrm{cm} .\end{array}$ & $\begin{array}{c}\text { Toplam } \\
\text { Azot } \\
\%\end{array}$ & $\begin{array}{c}\text { Yarayişl1 } \\
\text { Fosfor } \\
\text { ppm }\end{array}$ & $\begin{array}{c}\text { Yarayışl1 } \\
\text { Potasyum } \\
\text { ppm }\end{array}$ & $\begin{array}{c}\text { Demir } \\
\text { ppm }\end{array}$ & $\begin{array}{c}\text { Bakir } \\
\text { ppm }\end{array}$ & $\begin{array}{l}\text { Çinko } \\
\text { ppm }\end{array}$ & $\begin{array}{c}\text { Mangan } \\
\text { ppm }\end{array}$ \\
\hline \multirow{16}{*}{ 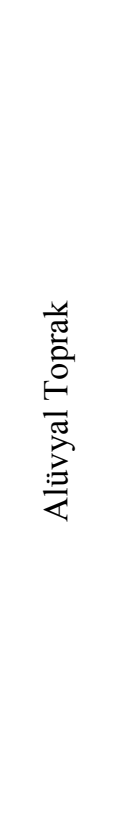 } & \multirow[t]{2}{*}{1} & $0-30$ & 0.119 & 6.32 & 88.20 & 8.24 & 0.93 & 0.80 & 14.67 \\
\hline & & $30-60$ & 0.089 & 19.55 & 84.30 & 8.01 & 0.91 & 0.72 & 13.48 \\
\hline & \multirow[t]{2}{*}{2} & $0-30$ & 0.133 & 22.11 & 136.50 & 9.74 & 0.83 & 0.67 & 13.14 \\
\hline & & $30-60$ & 0.116 & 21.37 & 114.60 & 5.00 & 0.83 & 0.63 & 13.62 \\
\hline & \multirow[t]{2}{*}{3} & $0-30$ & 0.109 & 22.23 & 54.60 & 10.20 & 1.03 & 0.69 & 13.02 \\
\hline & & $30-60$ & 0.075 & 22.62 & 57.60 & 9.39 & 1.01 & 0.80 & 12.36 \\
\hline & \multirow[t]{2}{*}{4} & $0-30$ & 0.061 & 12.93 & 133.50 & 10.06 & 0.87 & 0.67 & 13.05 \\
\hline & & $30-60$ & 0.029 & 14.25 & 50.10 & 8.80 & 0.61 & 0.60 & 11.42 \\
\hline & \multirow[t]{2}{*}{5} & $0-30$ & 0.085 & 15.39 & 205.20 & 2.07 & 0.82 & 0.71 & 18.63 \\
\hline & & $30-60$ & 0.061 & 16.24 & 252.80 & 2.02 & 0.84 & 0.50 & 17.81 \\
\hline & \multirow[t]{2}{*}{6} & $0-30$ & 0.075 & 7.12 & 107.20 & 3.67 & 0.86 & 0.68 & 16.29 \\
\hline & & $30-60$ & 0.070 & 8.72 & 129.60 & 2.54 & 0.62 & 0.80 & 16.11 \\
\hline & \multirow[t]{2}{*}{7} & $0-30$ & 0.047 & 3.19 & 129.80 & 2.42 & 1.08 & 0.75 & 9.60 \\
\hline & & $30-60$ & 0.046 & 3.19 & 166.80 & 2.20 & 0.36 & 0.20 & 10.14 \\
\hline & \multirow[t]{2}{*}{8} & $0-30$ & 0.130 & 3.64 & 79.60 & 2.27 & 0.82 & 0.69 & 25.32 \\
\hline & & $30-60$ & 0.103 & 5.70 & 78.70 & 3.12 & 0.84 & 0.80 & 26.14 \\
\hline \multirow{8}{*}{$\begin{array}{l}\frac{y}{\pi} \\
\frac{\pi}{0} \\
0 \\
0 \\
\vdots \\
\vdots \\
0 \\
0 \\
0\end{array}$} & \multirow[t]{2}{*}{9} & $0-30$ & 0.078 & 11.91 & 94.50 & 10.13 & 0.68 & 0.76 & 9.81 \\
\hline & & $30-60$ & 0.067 & 15.56 & 112.50 & 9.08 & 0.65 & 0.54 & 10.08 \\
\hline & \multirow[t]{2}{*}{10} & $0-30$ & 0.079 & 20.57 & 97.20 & 10.34 & 0.69 & 0.70 & 10.17 \\
\hline & & $30-60$ & 0.051 & 16.30 & 102.30 & 10.02 & 0.40 & 0.61 & 8.72 \\
\hline & \multirow[t]{2}{*}{11} & $0-30$ & 0.082 & 14.42 & 61.80 & 8.00 & 0.73 & 0.68 & 10.14 \\
\hline & & $30-60$ & 0.068 & 10.83 & 80.40 & 7.51 & 0.80 & 0.70 & 9.41 \\
\hline & \multirow[t]{2}{*}{12} & $0-30$ & 0.100 & 11.97 & 56.40 & 8.06 & 0.74 & 0.67 & 5.22 \\
\hline & & $30-60$ & 0.077 & 6.44 & 72.90 & 8.10 & 0.64 & 0.50 & 7.54 \\
\hline \multirow{8}{*}{ 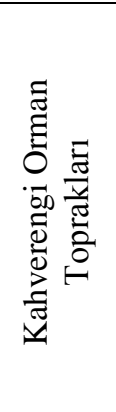 } & \multirow[t]{2}{*}{13} & $0-30$ & 0.040 & 3.64 & 178.80 & 1.52 & 0.30 & 0.81 & 11.61 \\
\hline & & $30-60$ & 0.032 & 7.01 & 193.20 & 1.53 & 0.26 & 0.78 & 10.16 \\
\hline & \multirow[t]{2}{*}{14} & $0-30$ & 0.065 & 5.30 & 183.60 & 2.76 & 0.90 & 0.67 & 4.98 \\
\hline & & $30-60$ & 0.058 & 1.65 & 127.20 & 2.54 & 0.79 & 0.70 & 5.64 \\
\hline & \multirow[t]{2}{*}{15} & $0-30$ & 0.159 & 3.59 & 141.60 & 2.17 & 0.92 & 0.64 & 23.76 \\
\hline & & $30-60$ & 0.154 & 3.13 & 141.60 & 1.17 & 0.74 & 0.60 & 21.68 \\
\hline & \multirow[t]{2}{*}{16} & $0-30$ & 0.166 & 5.98 & 138.00 & 1.37 & 0.90 & 0.84 & 16.41 \\
\hline & & $30-60$ & 0.077 & 6.27 & 144.00 & 2.15 & 0.92 & 0.81 & 15.14 \\
\hline
\end{tabular}


Çizelge 3. (Devam)

\begin{tabular}{|c|c|c|c|c|c|c|c|c|c|}
\hline $\begin{array}{c}\text { Toprak } \\
\text { Grb. }\end{array}$ & $\begin{array}{c}\text { Örnek } \\
\text { No. }\end{array}$ & $\begin{array}{c}\text { Derinlik } \\
\mathrm{cm} .\end{array}$ & $\begin{array}{c}\text { Toplam } \\
\text { Azot } \\
\%\end{array}$ & $\begin{array}{c}\text { Yarayış1 } 1 \\
\text { Fosfor } \\
\text { ppm }\end{array}$ & $\begin{array}{c}\text { Yarayışlı } \\
\text { Potasyum } \\
\text { ppm }\end{array}$ & $\begin{array}{c}\text { Demir } \\
\text { ppm }\end{array}$ & $\begin{array}{l}\text { Bakır } \\
\text { ppm }\end{array}$ & Çinko ppm & Mangan ppm \\
\hline \multirow{8}{*}{ 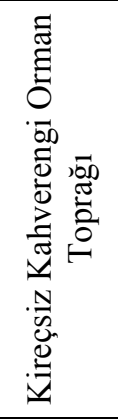 } & \multirow[t]{2}{*}{17} & $0-30$ & 0.051 & 8.55 & 150.00 & 1.03 & 1.14 & 0.69 & 11.70 \\
\hline & & $30-60$ & 0.047 & 3.99 & 99.60 & 1.39 & 1.08 & 0.66 & 11.81 \\
\hline & \multirow[t]{2}{*}{18} & $0-30$ & 0.092 & 10.26 & 128.40 & 2.01 & 0.48 & 0.71 & 11.25 \\
\hline & & $30-60$ & 0.089 & 5.64 & 102.60 & 1.10 & 0.42 & 0.84 & 10.87 \\
\hline & \multirow[t]{2}{*}{19} & $0-30$ & 0.098 & 3.36 & 97.80 & 1.33 & 0.92 & 0.67 & 10.08 \\
\hline & & $30-60$ & 0.092 & 4.10 & 116.50 & 1.83 & 0.55 & 0.66 & 9.92 \\
\hline & \multirow[t]{2}{*}{20} & $0-30$ & 0.127 & 2.67 & 140.10 & 1.12 & 0.86 & 0.67 & 13.41 \\
\hline & & $30-60$ & 0.113 & 3.42 & 126.80 & 2.34 & 0.71 & 0.82 & 14.55 \\
\hline \multirow{8}{*}{ 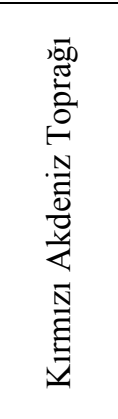 } & \multirow[t]{2}{*}{21} & $0-30$ & 0.018 & 17.84 & 203.40 & 5.39 & 1.90 & 1.60 & 8.97 \\
\hline & & $30-60$ & 0.015 & 29.01 & 179.40 & 5.54 & 1.30 & 1.80 & 8.90 \\
\hline & \multirow[t]{2}{*}{22} & $0-30$ & 0.056 & 8.15 & 158.70 & 5.08 & 1.32 & 1.69 & 10.08 \\
\hline & & $30-60$ & 0.028 & 9.51 & 152.40 & 4.92 & 1.40 & 1.63 & 9.60 \\
\hline & \multirow[t]{2}{*}{23} & $0-30$ & 0.056 & 8.55 & 75.00 & 6.69 & 1.10 & 0.92 & 25.35 \\
\hline & & $30-60$ & 0.042 & 8.03 & 72.90 & 5.70 & 1.58 & 0.74 & 24.48 \\
\hline & \multirow[t]{2}{*}{24} & $0-30$ & 0.028 & 8.66 & 96.60 & 5.75 & 1.80 & 3.22 & 12.90 \\
\hline & & $30-60$ & 0.014 & 10.57 & 98.70 & 5.42 & 2.30 & 2.88 & 9.62 \\
\hline \multirow{8}{*}{ 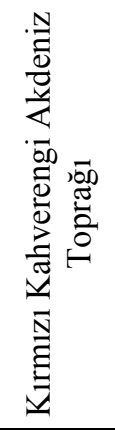 } & \multirow[t]{2}{*}{25} & $0-30$ & 0.107 & 11.51 & 131.40 & 2.92 & 1.22 & 1.84 & 21.51 \\
\hline & & $30-60$ & 0.075 & 11.97 & 132.00 & 2.62 & 1.14 & 1.80 & 20.47 \\
\hline & \multirow[t]{2}{*}{26} & $0-30$ & 0.172 & 5.07 & 54.60 & 2.30 & 1.25 & 3.77 & 12.81 \\
\hline & & $30-60$ & 0.149 & 5.64 & 57.00 & 2.37 & 1.18 & 2.90 & 13.83 \\
\hline & \multirow[t]{2}{*}{27} & $0-30$ & 0.068 & 5.70 & 60.00 & 2.24 & 1.22 & 0.68 & 12.48 \\
\hline & & $30-60$ & 0.058 & 5.52 & 56.70 & 2.20 & 1.23 & 0.38 & 11.24 \\
\hline & \multirow[t]{2}{*}{28} & $0-30$ & 0.074 & 8.72 & 60.90 & 2.90 & 0.88 & 0.80 & 7.02 \\
\hline & & $30-60$ & 0.050 & 9.06 & 63.00 & 1.80 & 0.51 & 0.50 & 8.03 \\
\hline \multirow{14}{*}{ 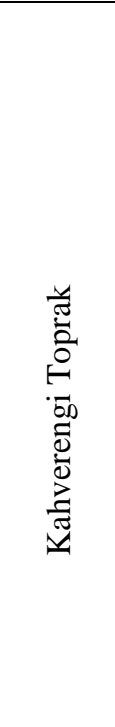 } & \multirow[t]{2}{*}{29} & $0-30$ & 0.165 & 6.30 & 193.20 & 3.82 & 1.70 & 0.42 & 11.97 \\
\hline & & $30-60$ & 0.120 & 4.23 & 156.90 & 3.22 & 1.10 & 0.42 & 10.26 \\
\hline & \multirow[t]{2}{*}{30} & $0-30$ & 0.169 & 10.19 & 215.90 & 3.60 & 0.80 & 0.64 & 13.14 \\
\hline & & $30-60$ & 0.059 & 18.78 & 220.20 & 3.70 & 0.16 & 0.44 & 12.10 \\
\hline & \multirow[t]{2}{*}{31} & $0-30$ & 0.161 & 10.25 & 165.00 & 4.02 & 1.14 & 0.62 & 12.62 \\
\hline & & $30-60$ & 0.113 & 26.00 & 82.80 & 3.12 & 1.90 & 0.40 & 7.86 \\
\hline & \multirow[t]{2}{*}{32} & $0-30$ & 0.098 & 7.16 & 180.00 & 3.30 & 0.24 & 0.60 & 11.98 \\
\hline & & $30-60$ & 0.028 & 4.69 & 110.40 & 3.10 & 0.14 & 0.50 & 10.64 \\
\hline & \multirow[t]{2}{*}{33} & $0-30$ & 0.182 & 7.26 & 91.80 & 3.10 & 1.36 & 1.04 & 10.60 \\
\hline & & $30-60$ & 0.158 & 6.35 & 83.10 & 3.26 & 1.46 & 0.48 & 12.16 \\
\hline & \multirow[t]{2}{*}{34} & $0-30$ & 0.212 & 21.65 & 240.20 & 1.84 & 0.97 & 2.74 & 12.26 \\
\hline & & $30-60$ & 0.182 & 10.94 & 168.00 & 2.30 & 0.64 & 3.94 & 10.92 \\
\hline & \multirow[t]{2}{*}{35} & $0-30$ & 0.072 & 7.16 & 109.50 & 2.62 & 0.42 & 0.50 & 10.64 \\
\hline & & $30-60$ & 0.033 & 8.87 & 110.40 & 1.80 & 0.26 & 0.44 & 11.46 \\
\hline
\end{tabular}


Çizelge 3. (Devam)

\begin{tabular}{|c|c|c|c|c|c|c|c|c|c|}
\hline $\begin{array}{c}\text { Toprak } \\
\text { Grb. }\end{array}$ & $\begin{array}{c}\text { Örnek } \\
\text { No. }\end{array}$ & $\begin{array}{c}\text { Derinlik } \\
\mathrm{cm} .\end{array}$ & $\begin{array}{c}\text { Toplam } \\
\text { Azot } \\
\%\end{array}$ & $\begin{array}{c}\text { Yarayış1 } 1 \\
\text { Fosfor } \\
\text { ppm }\end{array}$ & $\begin{array}{c}\text { Yarayış1 } 1 \\
\text { Potasyum } \\
\text { ppm }\end{array}$ & Demir ppm & $\begin{array}{c}\text { Bakır } \\
\text { ppm }\end{array}$ & Çinko ppm & $\begin{array}{c}\text { Mangan } \\
\text { ppm }\end{array}$ \\
\hline \multirow{8}{*}{ 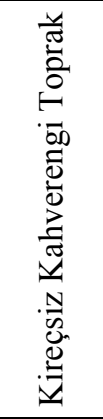 } & \multirow[t]{2}{*}{36} & $0-30$ & 0.063 & 2.90 & 29.20 & 5.40 & 0.52 & 0.68 & 15.69 \\
\hline & & $30-60$ & 0.056 & 3.36 & 31.50 & 4.20 & 0.52 & 0.70 & 14.75 \\
\hline & \multirow[t]{2}{*}{37} & $0-30$ & 0.137 & 5.81 & 87.60 & 1.53 & 1.08 & 1.34 & 20.07 \\
\hline & & $30-60$ & 0.120 & 5.98 & 90.00 & 1.22 & 1.07 & 1.24 & 21.14 \\
\hline & \multirow[t]{2}{*}{38} & $0-30$ & 0.102 & 10.77 & 39.60 & 6.84 & 0.86 & 1.74 & 19.56 \\
\hline & & $30-60$ & 0.098 & 10.83 & 42.00 & 5.40 & 0.72 & 1.71 & 18.78 \\
\hline & \multirow[t]{2}{*}{39} & $0-30$ & 0.128 & 14.36 & 35.10 & 1.53 & 0.30 & 1.55 & 18.39 \\
\hline & & $30-60$ & 0.124 & 14.53 & 36.00 & 1.40 & 0.22 & 1.58 & 18.01 \\
\hline \multirow{20}{*}{ 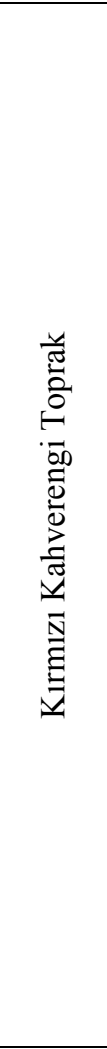 } & \multirow[t]{2}{*}{40} & $0-30$ & 0.200 & 34.08 & 609.60 & 10.20 & 2.39 & 3.40 & 28.65 \\
\hline & & $30-60$ & 0.142 & 38.47 & 448.20 & 9.84 & 2.12 & 3.47 & 24.81 \\
\hline & \multirow[t]{2}{*}{41} & $0-30$ & 0.312 & 40.01 & 544.20 & 13.95 & 2.18 & 3.55 & 19.59 \\
\hline & & $30-60$ & 0.239 & 39.84 & 546.00 & 11.04 & 1.45 & 2.72 & 19.02 \\
\hline & \multirow[t]{2}{*}{42} & $0-30$ & 0.246 & 34.08 & 406.50 & 12.42 & 1.56 & 1.32 & 8.67 \\
\hline & & $30-60$ & 0.217 & 34.25 & 408.00 & 10.10 & 0.78 & 1.08 & 10.64 \\
\hline & \multirow[t]{2}{*}{43} & $0-30$ & 0.184 & 33.80 & 402.00 & 12.52 & 2.11 & 3.31 & 6.69 \\
\hline & & $30-60$ & 0.165 & 39.61 & 647.40 & 11.30 & 2.02 & 2.67 & 6.78 \\
\hline & \multirow[t]{2}{*}{44} & $0-30$ & 0.315 & 23.48 & 225.60 & 7.30 & 1.32 & 0.90 & 12.06 \\
\hline & & $30-60$ & 0.323 & 9.27 & 157.20 & 5.86 & 0.38 & 0.66 & 12.82 \\
\hline & \multirow[t]{2}{*}{45} & $0-30$ & 0.214 & 15.40 & 175.80 & 8.44 & 1.04 & 1.24 & 11.62 \\
\hline & & $30-60$ & 0.154 & 11.16 & 127.20 & 8.74 & 0.42 & 1.04 & 11.26 \\
\hline & \multirow[t]{2}{*}{46} & $0-30$ & 0.028 & 19.27 & 175.50 & 4.24 & 1.64 & 0.74 & 8.30 \\
\hline & & $30-60$ & 0.003 & 18.78 & 218.10 & 4.82 & 0.44 & 1.00 & 8.60 \\
\hline & \multirow[t]{2}{*}{47} & $0-30$ & 0.007 & 28.86 & 187.80 & 3.98 & 1.14 & 0.90 & 7.24 \\
\hline & & $30-60$ & 0.056 & 7.44 & 119.70 & 5.48 & 0.84 & 0.97 & 8.10 \\
\hline & \multirow[t]{2}{*}{48} & $0-30$ & 0.021 & 6.52 & 135.30 & 3.56 & 0.14 & 0.50 & 11.66 \\
\hline & & $30-60$ & 0.042 & 18.61 & 81.00 & 2.98 & 0.96 & 0.37 & 11.20 \\
\hline & \multirow[t]{2}{*}{49} & $0-30$ & 0.010 & 8.30 & 199.80 & 4.24 & 1.30 & 0.68 & 11.48 \\
\hline & & $30-60$ & 0.010 & 17.92 & 73.80 & 3.58 & 0.96 & 0.38 & 9.60 \\
\hline \multirow{8}{*}{ 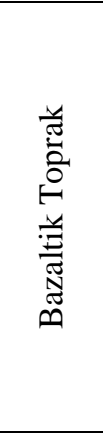 } & \multirow[t]{2}{*}{50} & $0-30$ & 0.007 & 18.80 & 147.00 & 6.13 & 1.38 & 1.00 & 10.14 \\
\hline & & $30-60$ & 0.005 & 18.98 & 148.20 & 5.50 & 1.21 & 1.08 & 7.38 \\
\hline & \multirow[t]{2}{*}{51} & $0-30$ & 0.026 & 23.71 & 148.80 & 6.88 & 2.10 & 1.70 & 14.76 \\
\hline & & $30-60$ & 0.021 & 21.83 & 141.60 & 4.46 & 1.80 & 1.30 & 15.58 \\
\hline & \multirow[t]{2}{*}{52} & $0-30$ & 0.092 & 15.73 & 135.00 & 7.38 & 1.67 & 1.29 & 13.56 \\
\hline & & $30-60$ & 0.061 & 25.56 & 125.40 & 7.26 & 1.46 & 1.30 & 13.08 \\
\hline & \multirow[t]{2}{*}{53} & $0-30$ & 0.039 & 50.27 & 304.80 & 8.32 & 3.50 & 3.29 & 21.33 \\
\hline & & $30-60$ & 0.035 & 44.97 & 264.00 & 6.47 & 2.80 & 3.02 & 20.24 \\
\hline \multicolumn{3}{|c|}{ En Büyük } & 0.323 & 50.27 & 647.40 & 13.95 & 3.50 & 3.94 & 28.65 \\
\hline \multicolumn{3}{|c|}{ En Küçük } & 0.003 & 1.65 & 29.20 & 1.03 & 0.14 & 0.20 & 4.98 \\
\hline \multicolumn{3}{|c|}{ Ortalama } & 0.095 & 13.88 & 153.10 & 4.99 & 1.04 & 1.16 & 13.26 \\
\hline
\end{tabular}


Toprakların bazı özellikleri ile alınabilir besin maddeleri arasındaki ilişkiler

Büyük toprak gruplarına göre toprak özelliklerinin biri birleri ve bazı besin elementleri ile ilgili korelasyon katsayıları ve onlara ait regresyon denklemleri Çizelge 4'de verilmiştir.

Çizelge 4. Bazı toprak özelliklerinin biri birleri ve bazı besin elementleri ile ilgili korelasyon (r) katsayıları ve regresyon denklemleri

\begin{tabular}{|c|c|c|c|}
\hline \multicolumn{2}{|c|}{ Özellikler } & \multirow[b]{2}{*}{$\mathrm{R}$} & \multirow[b]{2}{*}{ Regresyon Denklemi } \\
\hline $\mathrm{X}$ & $\mathrm{Y}$ & & \\
\hline \multicolumn{4}{|c|}{ Aluviyal topraklar } \\
\hline Organik madde & $\mathrm{P}$ & $0.75^{* *}$ & $Y=12.007 X-45.202$ \\
\hline KDK & Kil & $0.66 * *$ & $Y=0.2472 X+29.440$ \\
\hline Kireç & $\mathrm{pH}$ & $0.75^{* *}$ & $Y=0.3091 X+7.449$ \\
\hline Kum & Kil & $-0.88^{* *}$ & $Y=-0.927 X+70.444$ \\
\hline \multicolumn{4}{|c|}{ Kolluviyal topraklar } \\
\hline Kireç & $\mathrm{pH}$ & $0.91 * *$ & $\mathrm{Y}=0.5811 \mathrm{X}+7.349$ \\
\hline Kireç & Tuz & $0.89 * *$ & $Y=1.0913 X+0.478$ \\
\hline Kil & Silt & $-0.92^{* *}$ & $Y=-0.9359 X+66.908$ \\
\hline \multicolumn{4}{|c|}{ Kahverengi Orman toprakları } \\
\hline Kil & KDK & $0.97 * *$ & $Y=0.2472 X+29.440$ \\
\hline Kum & Kil & $-0.98 * *$ & $Y=-0.6122 X+57.383$ \\
\hline Kum & KDK & $-0.97 * *$ & $Y=-0.3968 X+52.418$ \\
\hline \multicolumn{4}{|c|}{ Kireçsiz Kahverengi Orman toprakları } \\
\hline Organik madde & KDK & $0.94 * *$ & $Y=2.3773 X+29.916$ \\
\hline Tuz & Organik madde & $0.91 * *$ & $Y=1.2815 X-0.405$ \\
\hline $\mathrm{pH}$ & Organik madde & $-0.96 * *$ & $Y=-0.7671 X+6.259$ \\
\hline \multicolumn{4}{|c|}{ Kırmızı Akdeniz toprakları } \\
\hline Kireç & KDK & $0.94 * *$ & $Y=-0.3949 X+37.607$ \\
\hline Kireç & Tuz & $0.90 * *$ & $Y=0.323 X+0.277$ \\
\hline Kireç & $\mathrm{K}$ & $0.94 * *$ & $\mathrm{Y}=1.3772 \mathrm{X}+5.572$ \\
\hline KDK & Tuz & $-0.76^{*}$ & $Y=-0.0327 X+1.596$ \\
\hline KDK & $\mathrm{P}$ & $-0.88^{* *}$ & $Y=-2.5359 X+102.15$ \\
\hline Kum & $\mathrm{Cu}$ & $-0.76^{*}$ & $Y=-0.0878 X+4.420$ \\
\hline $\mathrm{pH}$ & $\mathrm{Zn}$ & $-0.78 *$ & $Y=-6.535 X+53.568$ \\
\hline \multicolumn{4}{|c|}{ Kırmızı Kahverengi Akdeniz toprakları } \\
\hline Kil & Silt & $-0.94 * *$ & $Y=-0.9875 X+72.603$ \\
\hline Kil & $\mathrm{K}$ & $-0.76^{*}$ & $Y=-4.3408 X+267.200$ \\
\hline \multicolumn{4}{|c|}{ Kahverengi topraklar } \\
\hline Kil & Silt & $-0.96 * *$ & $Y=-0.8545 X+66.401$ \\
\hline Kireç & $\mathrm{Zn}$ & $-0.62 *$ & $Y=-0.0309 X+1.966$ \\
\hline \multicolumn{4}{|c|}{ Kireçsiz Kahverengi toprakları } \\
\hline $\mathrm{pH}$ & KDK & $0.86 * *$ & $Y=72.734 X-487.34$ \\
\hline Kil & Silt & $-0.94 * *$ & $Y=-0.4431 X+49.334$ \\
\hline $\mathrm{pH}$ & $\mathrm{P}$ & $-0.90 * *$ & $Y=-66.146 X+479.11$ \\
\hline \multicolumn{4}{|c|}{ Kırmızı Kahverengi topraklar } \\
\hline Kil & Kum & $-0.87 * *$ & $Y=-1.5458 X+92.658$ \\
\hline Silt & Kum & -0.87 & $Y=-0.5008 X+45.446$ \\
\hline \multicolumn{4}{|c|}{ Bazaltik topraklar } \\
\hline $\mathrm{pH}$ & $\mathrm{P}$ & $-0.94 * *$ & $Y=-71.088 X+585.17$ \\
\hline Kum & Silt & $-0.95^{* *}$ & $Y=-0.8706 X+51.649$ \\
\hline
\end{tabular}

*, **; ile gösterilen korelasyon değerleri sırasıyla $\mathrm{P}<0.05$ ve $\mathrm{P}<0.01$ düzeyinde önemlidir.

Alüvyal topraklarda organik madde ile fosfor (r:0.75; $\mathrm{P}<0.01)$, KDK ile kil (r:0.66; $\mathrm{P}<0.01)$, kireç ile $\mathrm{pH}(\mathrm{r}: 0.75$ $\mathrm{P}<0.01)$ arasinda pozitif, kil ile kum $(\mathrm{r}:-0.88 ; \mathrm{P}<0.01)$ aralarında negatif önemli ilişkiler saptanmıştır. Benzer ilişkiler Turan ve ark. (2010) tarafindan yapılan bir çalışmada da bulunmuştur. Kolüvyal topraklarda, $\mathrm{pH}$ ile kireç (r: 0.91; $\mathrm{P}<0.01$ ), kireç ile tuz (r: 0.89; $\mathrm{P}<0.01$ ) aralarında pozitif, kil ile silt (r: $-0.92 ; \mathrm{P}<0.01)$, organik 
madde ile bakır (r: $-0.79 ; \mathrm{P}<0.05)$ aralarında negatif önemli ilişkiler belirlenmiştir. Kahverengi orman topraklarında, kil ile KDK (r:0.97; $\mathrm{P}<0.01)$ arasında pozitif, kum ile kil (r:0.98; $\mathrm{P}<0.01$ ), kum ile KDK (r:-0.97; $\mathrm{P}<0.01$ ) aralarında negatif önemli ilişkiler saptanmıştır. Orta Anadolu' da çeltik tarımı yapılan toprakların incelendiği bir çalışmada, kil ile KDK (r:0.74; $\mathrm{P}<0.001)$ arasında pozitif, kum ile kil (r:-0.63; $\mathrm{P}<0.001)$, kum ile KDK (r:-0.35; $\mathrm{P}<0.05)$ arasinda negatif önemli ilişkiler belirlenerek, çalışma ile benzer sonuçlar elde edilmiştir (Taban ve ark., 1997). Kireçsiz kahverengi orman topraklarında; organik madde ile KDK (r:0.94; $\mathrm{P}<0.01)$, tuz ile organik madde (r:0.91; $\mathrm{P}<0.01$ ) aralarında pozitif önemli ilişkiler belirlenmiş olup, $\mathrm{pH}$ ile organik madde $(\mathrm{r}:-0.96 ; \mathrm{P}<0.01)$ arasında negatif önemli ilişkiler belirlenmiştir. Kırmızı Akdeniz topraklarında; kireç-KDK (r:0.94; $\mathrm{P}<0.01)$, kireç-tuz (r:0.90; $\mathrm{P}<0.01)$ kireç-alınabilir K arasında pozitif, KDK ile tuz (r:-0.76; $\mathrm{P}<0.05)$, KDK ile alınabilir $\mathrm{P}(\mathrm{r}:-0.88 ; \mathrm{P}<0.01)$, Kum ile $\mathrm{Cu}$ (r:-0.76; $\mathrm{P}<0.05)$ ve $\mathrm{pH}$ ile $\mathrm{Zn}(\mathrm{r}:-0.78 ; \mathrm{P}<0.05)$, içerikleri aralarında negatif önemli ilişkiler saptanmıştır. Çelik ve Katkat (2005), Bursa ilinde şeftali yetiştiriciliği yapılan toprakların incelendiği bir çalışmada, Karaçal ve Çimrin (1997) Yüzüncü Yıl Üniversitesi araştırma çiftliği topraklarında yaptıkları çalışmada benzer ilişkiler belirlenmiştir. Kırmızı kahverengi Akdeniz topraklarında; Kil ile Silt (r:-0.94; $\mathrm{P}<0.01)$ ve Kil ile K $(-0.76$; $\mathrm{P}<0.05)$ aralarında negatif önemli ilişkiler belirlenmiştir. Benzer olarak, Eceabat ilçesi tarım topraklarının verimlilik durumlarının incelendiği bir çalışmada, toprakların organik madde ile potasyum ( $\mathrm{r}: 0.30 ; \mathrm{P}<0.01)$, organik madde ile mangan $(\mathrm{r}: 0.42 ; \mathrm{P}<0.01)$ arasinda pozitif, $\mathrm{pH}$ ile mangan (r:-0.26; $\mathrm{P}<0.01)$ arasında negatif önemli ilişkiler ile paralellik göstermektedir (Parlak ve ark., 2008). Kahverengi topraklarda; Kil ile Silt (r:-0.96; P<0.01) ve kireç ile $\mathrm{Zn}$ arasında negatif önemli ilişkiler bulunmuştur. Benzer ilişkiler Parlak ve ark. (2008), tarafindan yapılan bir çalışmada da yer almaktadır. Kireçsiz kahverengi topraklarda; organik madde ile mangan $(\mathrm{r}: 0.91 ; \mathrm{P}<0.01)$, $\mathrm{pH}$ ile KDK (r:0.86; $\mathrm{P}<0.01)$ aralarında pozitif, kil ile silt (r:-0.94; $\mathrm{P}<0.01)$, fosfor ile $\mathrm{pH}(\mathrm{r}:-0.9 ; \mathrm{P}<0.01)$ aralarında negatif önemli ilişkiler saptanmıştır (Çizelge 4). Bazı araştırıcılarda benzer ilişkileri bulduklarını belirtmişlerdir (Doran ve ark., 2008). Kırmızı kahverengi topraklarda; Kil ile kum (r:-0.87; $\mathrm{P}<0.01)$ ve silt ile kum (r:-0.87; $\mathrm{P}<0.01)$ arasında negatif önemli ilişkiler belirlenmiştir (Çizelge 4). Farklı yörelerde çalışan bazı araştırıcılarda benzer ilişkileri bulduklarını bildirmişlerdir (Atalay, 1988; Çimrin ve Boysan, 2006). Bazaltik topraklarda; fosfor ile $\mathrm{pH}$ (r:-0.94; $\mathrm{P}<0.01)$, kum ile silt ( $\mathrm{r}:-0.95 ; \mathrm{P}<0.01)$ arasinda negatif önemli ilişkiler bulunmuştur.

\section{SONUÇ}

Gaziantep ili topraklarının \% 65.11' inin killi, \% 27.35' inin killi tınlı ve \% 7.54' ünün kumlu killi tınlı bünyeye sahip olduğu belirlenmiştir. Ortalama kireç içeriği \% 7.87 olan yöre topraklarının ortalama pH's1 7.74 dür. Topraklarının \% 43.40' ının alkalin, \% 39.62' sinin hafif alkalin ve \% 16.98' inin nötr olduğu belirlenmiştir. Genelde toprak reaksiyonunun yüksek oluşu, demir ve çinko gibi mikro elementlerin yarayışlılığı azalttığı için kullanılacak gübrelerin şelat formunda toprağa uygulanması tavsiye edilmektedir. Gaziantep ili topraklarının tuz içeriklerinin \% 47.16' sının çok fazla tuzlu, \% 42.45' inin orta derecede tuzlu \% 10.39' unun hafif tuzlu olduğu belirlenmiştir. Toprakların tuz içeriklerinin yüksekliği de göz önüne alınarak gübreleme yapılırken tuz indeksi düşük olan gübrelerin kullanılmasına dikkat edilmelidir.. Yöre topraklarının tümü organik madde bakımından yetersiz olup yöre topraklarına mutlaka organik gübre kullanımı tavsiye edilmektedir. Gaziantep topraklarının toplam azot içeriklerinin \% 0.96' sının çok fazla, \% 11.32' sinin fazla, \% 32.07' sinin yeterli, \% 33.01' inin az, \% 22.64' ünün çok az olduğu belirlenmiştir. Özetle, \% 55.65' i azot bakımından yetersiz bulunan topraklarda öncelikle organik gübrelerin kullanılmasının yanı sıra piyasada bulunan azot içerikli gübrelerin kullanılması tavsiye edilmektedir. Gaziantep topraklarının yarayışlı fosfor içerikleri bakımından \% 13.20' sinin fazla, $\%$ 50.94' ünün yeterli, \% 34.90'ının az ve \% 0.96' sinın çok az olduğu belirlenmiştir. \% $\quad 35.86^{\prime}$ s1 fosfor bakımından yetersiz olan Gaziantep yöresi toprakları için fosfor içerikli gübrelerin kullanımı tavsiye edilmektedir. Topraklarının yarayışı potasyum içerikleri sinıflandırıldığında \% 8.49' unun fazla, \% 51.88' inin yeterli, \% 33.96' sının az ve \% 5.67' sinin çok az olarak belirlenmiştir. Özetle, \% 39.63' ünde yetersiz olarak belirlenen potasyumun eksikliğini gidermek amacıyla potasyum içerikli gübrelerin kullanımı tavsiye edilmektedir. Gaziantep ili topraklarının yarayışlı demir içerikleri sınıflandırıldığında \% 45.28' inin fazla, \% 25.48' inin orta, \% 29.24' ünün az derecede olduğu belirlenmiştir. Toprakların kil içerikleri göz önüne alındığında, demir eksikliğinin giderilmesi için "demir şelat" şeklinde bulunan gübrelerin uygulanması önerilebilir. Gaziantep topraklarının yarayışlı bakır içerikleri sınıflandırıldığında \% 97.16' sının yeterli, çok az yaklaşık \% 2.84' ünün yetersiz olduğu belirlenmiştir. Gaziantep topraklarının yarayışlı çinko içerikleri sınıflandırıldığında \% 9.44' ünün fazla, \% 47.16' sının yeterli, \% 43.40' ının az olduğu belirlenmiştir. Yarısına yakınında çinko eksikliği görülen topraklarda şelatlı gübrelerin toprağa verilmesi problemin giderilmesine yardımcı olacaktır. Gaziantep topraklarının yarayışlı mangan içerikleri sınıflandırıldığında tamamının yeterli olduğu belirlenmiştir. Sonuç olarak yöre topraklarının \%30'u $\mathrm{Fe}$ ve \%43'ü $\mathrm{Zn}$ gübrelemesine şiddetle ihtiyaç duyarken, toprakların \% 56'sı azotlu, \%36's1 fosforlu ve \%40'1 K lu gübrelerce desteklenmeye ihtiyaç duymaktadır.

\section{KAYNAKLAR}

Allison, L., Moodie. E. C.D., 1965. Carbonate in: C.A. Black et al. (Ed.) Methods of Soil Analysis, Part 2, Agronomy: 1379-1400. Am. Soc. of Agron. Inc., Madison, Wisconsin, USA.

Anonim, 1988. Türkiye gübreler ve gübreleme rehberi. Toprak ve Gübre Araştırma Enstitüsü Müdürlüğü Genel Yayın No: 151, Teknik Yayınlar No:T-59. 
Anonim, 1992. Gaziantep ili arazi varlığı. Köy Hizmetleri Genel Müdürlüğü Yayınları, İl Rapor No: 27.

Atalay, İ.Z. 1988. Gediz Havzası Rendzina Topraklarının Besin Elementi Durumu ve Bunların Bazı Toprak Özellikleri İle İlişkileri. Ege Üniv. Zir. Fak. Dergisi, 25(2): 173-184.

Bouyoucous, G. J. 1951. A recalibration of hydrometer method for making mechanical analysis of soils, Agronomy Journal, 43: 434 - 438.

Bremner, J.M. 1965. Total Nitrojen. In C.A. Black et al. (ed), Methods of Soil Analysis, Part 2, Agronomy 9: 1149-1178. Am. Soc. of Agron. Inc. Madison, Wisconsin, USA.

Chapman, H. D., Pratt, P. F. 1961. Methods of analysis for soils, plants and waters, pg: 1 - 309. University of California, Division of Agricultural Sciences, USA.

Çelik, H., Katkat, A. V. 2005. Bursa ili şeftali yetiştiriciliği yapılan tarım topraklarının potasyum durumu ve demir klorozu ile ilişkisi. Tarımda Potasyumun Yeri ve Önemi Çalıştayı, s: 74-84.

Çimrin, K. M. ve Boysan, S. 2006. Van yöresi tarım topraklarının besin elementi durumları ve bunların bazı toprak özellikleriyle ilişkileri, YYU Ziraat Fakültesi Tarım Bilimleri Dergisi, 16: 105 - 111.

Doran, İ., Koca, Y. K., Pekkolay, B., Mungan, M. 2008. Derik Yöresi Zeytinliklerinin Beslenme Durumunun Tespiti. AÜ Ziraat Fakültesi Dergisi, 21 (1):131-138.

Düzgüneş, O., Kesici, T., Kavuncu, O., Gürbüz, F. 1987. Araştırma ve deneme metotları (İstatistik Metodlar1-II), A. Ü. Z. Yayınları, 1921, 381.

Eryüce, N., Taysun, A., Uysal, H., Dağdeviren, İ. 1993. Adıyaman, Batman, Diyarbakır, Elazı̆̆ Gaziantep, Malatya, Mardin, Siirt, Şanlıurfa, Şırnak civarındaki bazı eğimli ve düz tarım arazilerinde işlenen tabakanın $\mathrm{Fe}, \mathrm{Zn}, \mathrm{Mn}, \mathrm{Cu}$ içerikleri. Ege Üniversitesi Ziraat Fakültesi Dergisi, 30 (3): 81-88.

Follet, R. H., Lindsay, W. L. 1970. Profil distrubition of zinc, iron, manganese, and copper in Colorado soils. Colo. State. Univ. Exp. sta. Bull. S: 110.

Follet, R. H., Lindsay, W. L. 1978. Profile distribution of $\mathrm{Zn}, \mathrm{Fe}, \mathrm{Mn}$, and $\mathrm{Cu}$ in Colorado soils. Colorado Exp. Station Tech. Bull. S: 110.

Jackson, M. 1958. Soil chemical analysis. Prentice-Hall Inc., Englewood Cliffs, pg: 1 - 498, New Jersey, USA.

Karaçal, İ., Çimrin, K. M. 1997. Yüzüncü Yıl Üniversitesi kampüs alanı toprak profillerinin $\mathrm{Zn}$ durumu ve bu elementin bazı toprak özellikleri ile ilişkileri. I. Ulusal Çinko Kongresi, 12-16 Mayıs, Eskişehir.

Kellogg, C.E. 1952. Our garden soils. New York: The Macmillan Company, s. 232.

Köksal, İ., Okay, Y., Köroğlu, M., Güneş Tuna, N., Alagöz, R., Aplaslan, M. 2003. Antepfistığında Periyodisite Üzerine Etkili Faktörlerin ve Etki Düzeylerinin Belirlenmesi. TÜBİTAK Yay. Proje No: Togtag / Tarp - 1782, Sy: 10.
Lindsay, W. L., Norvell, W. A. 1978. Development of a DTPA soil test for $\mathrm{Zn}, \mathrm{Fe}, \mathrm{Mn}$, and $\mathrm{Cu}$. Soil Science Society of American Journal, 42: 421 - 428.

Olsen, S. R., Cole, C. V., Waterable, F. S., Dean, L. A. 1954. Estimation of available phosphorus in soils by extraction with sodium bicarbonate. USPA Circular No: 939, Washington D.C.

Özyazıc1, A., Aydoğan, M., Bayraklı, B., Dengiz, O. 2013. Doğu Karadeniz Bölgesi kırmızı-sarı podzolik toprakların temel karakteristik özellikleri ve verimlilik durumu. Anadolu Tarım Bilim. Derg., 28(1):24-32.

Parlak, M., Fidan, A., Kizılcık, İ., Koparan, H. 2008. Eceabat İlçesi (Çanakkale) Tarım Topraklarının Verimlilik Durumlarının Belirlenmesi. Tarım Bilimleri Dergisi, 14(4):394-400.

Pratt, P. F. 1965. Potassium. Method of soil analysis, Part 2, Chemical and microbiological properties, 2nd. Ed, A. L. Page, Amer, Soc, of Argon, Inc, Pub, Argon, Series No: 9.

Richard, L. A. 1954. Diagnosis and improvement of saline and alkaline soils. Handbook 60, U. S. Deptartment of Agriculture.

Sillanpää, M. 1990. Micronutrient assessment at the country level: An international study. In : FAO Soils Bulletin, N. 63.

Taban, S., Alpaslan, M., Hasemi, A. G., Eken, D. 1997. Orta Anadolu' da çeltik tarımı yapılan toprakların bazı fiziksel ve kimyasal özellikleri. Pamukkale Üniversitesi Mühendislik Fakültesi Mühendislik Bilimleri Dergisi, 3 (3): 457-466.

Taban, S., Çıkılı, Y., Kebeci, F., Taban, N., Sezer, S. M. 2004. Taşköprü yöresinde sarımsak tarımı yapılan toprakların verimlilik durumu ve potansiyel beslenme problemlerinin ortaya konulması. Tarım Bilimleri Dergisi, 10 (3): 297-304.

Tunç, E., Özkan, A. 2010. Gaziantep'in Tarım Topraklarında Erozyon Sorunu ve Bu Konuda Çiftçi Eğitimi. E.Ü. Fen Bilimleri Enstitüsü Dergisi, 3(2):143-153.

Turan, M.A., Katkat, A.V., Özsoy, G., Taban, S. 2010. Bursa İli Alüviyal Tarım Topraklarının Verimlilik Durumları ve Potansiyel Beslenme Sorunlarının Belirlenmesi. U. Ü. Ziraat Fakültesi Dergisi, 24(1):115-130.

Tüzüner, A. 1990. Toprak ve Su Analiz Laboratuvarları El Kitabı. T.C. Tarım Orman ve Köyişleri Bakanlığı, Köy Hizmetleri Genel Müdürlüğü Yayınları, Ankara

Ülgen, N., Yurtsever, N. 1995. Türkiye Gübre ve Gübreleme Rehberi. Toprak ve Gübre Araş. Ens. Teknik Yayınları., Genel Yayın No: 209, Teknik Yayınlar No: T - 66.

Walkley, A., Black, I. A. 1934. An examination of the degtjareff method for determining soil organic matter, and a proposed modification of the chromic acid titration method. Soil Science, 37(1):29-38. 